\title{
Social ethics in South Africa: Initiating a dialogue between its relevance and current status
}

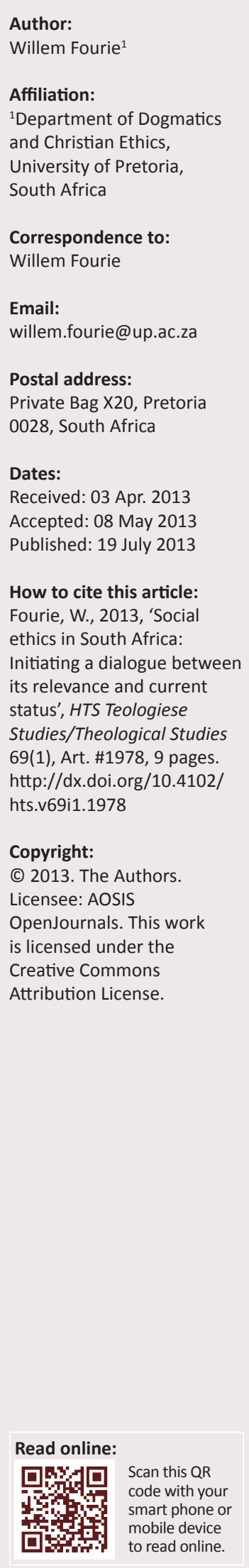

South African biblical scholars - particularly those who focus on the Old Testament - are known for their engagement with themes that can be termed social ethical. This impulse is used as starting point to investigate the relevance of social ethics in South Africa and its current status. It is argued that social ethical reflection is of particular relevance for South Africa. This thesis is investigated in two ways. Firstly, the applicability of social ethics as academic field is examined and it is shown that post-apartheid South African political institutions, systems and processes themselves are subjected to major changes and developments - a traditional area of focus of social ethics. Secondly, the current status of social ethical reflection in theological journals based in South Africa is investigated. The article concludes by showing that the current status of social ethical reflection in South African academic theology does not reflect the perceived need for social ethical reflection.

\section{On the Bible and Christian ethics}

There are probably Christian ethicists who would like to believe that Old Testament scholars either are not interested or are not supposed to engage in ethical reflection. At most, some would argue, those fellow theologians who study the Old Testament - and indeed also the New Testament should confine themselves to reflection on ethics within the Old Testament. But reflection on what this could mean within complex contemporary realities should be left, so some arguments go, to practitioners of systematic theology, particularly ethicists.

There is an element of truth in these arguments. Systematic theology and in particular Christian ethics are complex fields with centuries of accumulated knowledge and experience - this means that scholars need to spend a significant amount of time in acquiring and integrating these resources. There is of course a difference between acknowledging this element of truth and absolutising it. The latter would require denying the ethical thrust of biblical texts. However, acknowledging the ethical thrust of many Old Testament texts whilst respecting the integrity of Christian ethics as an academic field is by no means an uncomplicated endeavour, as can best be illustrated with reference to scholars who have attempted to do this. James Loader is an important example in this regard.

In his doctoral dissertation - entitled 'Aspekte van menslike mag in die Ou Testament' [Aspects of Human Power in the Old Testament] and completed in 1975 at the University of Groningen - he had already investigated a phenomenon with implications for both Old Testament studies and Christian ethics. This was followed by studies on Johannes Pederson's concept of power (Loader 1979, 1980). In 1984 Loader continued his investigation into the relation between ethics and the Old Testament with a further dissertation, this time at the University of South Africa, on Old Testament ethicists in the Netherlands between 1870 and 1914 (Loader 1984). These studies were complemented by his work during this time on socio-political realities in South Africa (Loader 1971) and in the Bible (Loader 1982). In a rather unorthodox move Loader received the Diploma in Environmental Education from South Africa's National Parks Board, for studies which focused his ethical reflection on environmental issues. This is illustrated in, for example, his contribution 'Image and Order: Old Testament Perspectives on the Ecological Crisis' (Loader 1987), 'Life, wonder and responsibility: Some thoughts on ecology and Christian mission' (Loader 1991a), 'Omgewing, lewe en belewing: Oor homo religiosus, die kunste en die omgewing' [Environment, life and experience: On homo religiosus, the arts and the environment] (Loader 1991b) and 'Seeing God with natural eyes: On Job and nature' (Loader 1992). In his more recent work Loader also returns to themes related either to ethics within the Old Testament, or to ethics emanating from the Old Testament, for example, the contributions 'Alttestamentliche Notizen zum Thema "Evangelische Kirchen und Demokratie"' [Notes from the Old Testament on the theme 'Protestant Churches and Democracy'] (Loader 2002), 'Virtue between command and advice' (Loader 2004b), 'Begegnung mit Gott als Zentralbegriff der niederländischen "Ethischen Theologie"' [Encounter with God as 
central motive of Dutch 'Ethical Theology] (Loader 2004a), a clear reference to the research conducted for his work on his dissertation at the University of South Africa, and 'The problem of money in the hand of a fool' (Loader 2012).

Two features of the articles highlighted above may be noted. It is clear, firstly, that Loader is an expert of the Old Testament who does not attempt to 'jump over his own shadow', but who engages ethical themes consistently from within his core field of expertise. The second feature relates to the ethical themes that he chooses to engage with. His research on power and on political, economic and environmental issues can be viewed as contributions not simply to the field of Christian ethics, but more specifically to social ethics as one of its constitutive fields. It is this feature of Loader's work - and in fact the work of a number of other Old Testament scholars originating from or working in South Africa - that has provided the impetus for the argument that will be presented here and outlined below.

In this article the focus will not fall on methodological issues related to integrating research in the biblical sciences into Christian ethical reflection. The ethical thrust of certain elements of James Loader's work will motivate self-critical reflection on certain elements of contemporary Christian ethical reflection in South Africa. It will be argued that social ethical reflection - of which elements can be found in the work of Loader - is of particular relevance for South Africa. This thesis will be investigated in two ways. Firstly, the applicability of social ethics as academic field is investigated, and it is shown to what extent it is of relevance for South Africa. Secondly, the current status of social ethical reflection in theological journals based in South Africa is investigated. The article concludes with the initiation of a dialogue between the perceived need for social ethical reflection in South Africa and its current status in theological reflection.

\section{On social ethics and South Africa}

Social ethics is the sub-discipline of Christian ethics concerned with the norms of institutions, systems and processes, and much of its genesis can be traced to German Protestant reflections on the subject. Classic works on social ethics in Protestant Theology include Einführung in die Sozialethik [Introduction to social ethics] by Heinz-Dietrich Wendland (1971), Sozialethik: Theologische Grundfragen [Social ethics: Fundamental theological questions] by Ernst Wolf (1975), Grundriss der Sozialethik [Compendium of social ethics] by Martin Honecker (1995) and Evangelische Sozialethik [Protestant social ethics] by Ulrich Körtner (1999). Since 2007 the Jahrbuch Sozialer Protestantismus [Yearbook of social Protestantism] has served as one of the most important compendiums for social ethical thought. In its inaugural edition Heinrich Bedford-Strohm, Traugott Jähnichen, Sigrid Reihs, Hans-Richard Reuter and Gerhard Wegner identify ten theses that express consensus in the field on ten basic principles (Bedford-Strohm et al. 2007:11-14). The first of these principles is that Protestant social ethics, firstly proceeds from the core conviction of the Reformation: God bestows inalienable dignity on every person. Being human is therefore never a means to an end but always an end in itself. The social ethicist Wolfgang Huber, citing Theodor Heuß (2004) and referencing Immanuel Kant, draws a distinction between a human person who has worth (Wert) and dignity (Würde):

One speaks of value when something can be replaced by its equivalent. Something with values therefore also has a price. Something with dignity, on the other hand, has no price and no equivalent. ${ }^{1}$ (n.p.)

The second principle is that the dignity bestowed by God, moves the individual beyond herself or himself to serve others in love. Or in the words of Bedford-Strohm et al. (2007:11): in love persons participate in God's reality. This is closely connected to the third principle: in the realisation of their inalienable dignity, persons discover their particular abilities and gifts. These first three principles provide the basis for a social ethical vision for society.

Accordingly, the fourth principle is that a just society must function in such a way that societal institutions such as the state, the economy, science and civil society should not only respect the dignity of all people, but enable the expansion of the freedom of the individual. Here one finds the same figure of thought present in the primary principle on human dignity: the dignity and freedom of individuals are not means to ends, but are the ends of society itself. The application of this principle can be found in the social ethical document Gerechte Teilhabe released by the Evangelical Church in Germany (EKD) in 2006. A just society is described as a society in which participatory justice (Beteiligungsgerechtigkeit), enabling justice (Befähigungsgerechtigkeit) and distributive justice (Verteilungsgerechtigkeit) are realised. In fact, in social ethics participatory justice connects enabling and distributive justice (EKD 2006:44). This means that, in terms of the fifth principle, dignity and freedom are promoted where people have the experience that in realising their calling they can care for themselves and others. The space for people to be able to realise their callings - in effect a society in which dignity and freedom are respected - is dependent on the sixth principle, namely the extent to which justice enables equal opportunities for all (Chancengleichheit). This is only possible when societal structures are transparent and accessible, and where all have access to socially just educational opportunities.

The next three principles all relate to what can be regarded as just systems of creating and distributing wealth. Principle seven reflects on the status of wealth and property, and concludes that they should be regarded as gifts of which human beings are the custodians. The unequal distribution of wealth and property is only acceptable in social ethical terms to the extent that it leads to the betterment of the situation of the weakest members of society. However - the eighth principle continues - if a system of distribution impairs the freedom and dignity of all to realise their calling in service to others, and produces the enslavement to wealth and

1.'Von Wert spricht man dort, wo eine Sache durch ein Aqquivalent ersetzt werden kann; was einen Wert hat, hat damit auch einen Preis. Würde dagegen hat das, "was ... über allen Preis erhaben ist, mithin kein Äquivalent verstattet"." 
property as ends in themselves, then the system itself should be condemned. This principle clearly implies a potentially fundamental critique of some versions of capitalism. This is why the ninth principle reaffirms the social market economy in which the values of freedom, solidarity and justice receive consideration.

The concluding principle affirms the potential of social ethics to make a contribution to developing humane systems, institutions and societal processes. It deals with:

the ability of social ethics to provide orientation amidst contemporary upheavals in the economy and society, in the context of globalisation, to develop humane and relevant solutions in the face of real economic, social, political and employment challenges. (Bedford-Strohm et al. 2007:14)

Even this characterisation of social ethics from a decidedly developed perspective shows its relevance to South African realities.

In post-apartheid South Africa institutions, systems and processes themselves are subjected to major changes and developments. In order to illustrate the extent of the changes, and eventually the relevance of social ethics in South Africa, the country's key political changes and developments will be discussed from an external and an internal perspective.

South Africa's political changes are not taking place in isolation from global and regional developments - here we adopt an external perspective - and taking cognisance of these developments is of fundamental importance in understanding the extent and impact of the changes in South Africa. Democratically elected governments worldwide are confronted with rather dramatic changes in their role and in citizens' legitimate expectations. The 'crisis of the welfare state' or 'crisis of the nation state' (cf. Castells 2010) is often cited as one of the most important changes facing constitutional democracies (cf. Garriga \& Melé 2008:84). Worldwide democratically elected governments are experiencing difficulty in providing for the basic human needs of all their citizens. This is especially the case in countries with consolidating democratic institutions and developing economies, such as South Africa. A further challenge faced by these governments is the regulation and control of economic activities. New spaces are being created outside the borders of national states (Crane, Matten \& Spence 2008a:457). Multinational companies are becoming more mobile, and their ability to relocate to countries on grounds of their favourable regulatory environment adds to the pressure on national governments. Governments are consequently 'reluctant to impose extra regulation on business for fear of losing employment and tax income' (Crane, Matten \& Spence 2008b:23).

These processes can be expressed in social ethical terms with reference to the German protestant social ethicist Wolfgang Huber's analysis of the changing global flows of justice (Huber 1996:155-156). He identifies the growing dominance of iustitia commutativa (often translated as 'corrective justice') in modern democracies as a major social ethical problem
(Huber 1996:151-156). However, in order to appreciate his analysis, we first need to take note of a number of key moments in the development of the concept of justice, following Huber's presentation.

Aristotle distinguished between justice in a broad and in a narrow sense. Iustitia legalis - often translated as 'legal justice'- refers to justice in the broad sense and it describes the citizen's duty to respect the law. Iustitia legalis organises both the citizen's relationship to the polis [city], as well as the public relationships citizens may have with one another. To refer to justice in the narrow sense he made use of two terms, namely what was later transcribed into Latin as iustitia distributiva (distribute justice; Greek: dianemetikon dikaion) and iustitia correctiva (corrective justice; Greek: diorthikon dikaion) (Huber 1996:152). In terms of iustitia distributiva [distributive justice] the citizen is assigned goods and positions according to the social order of society. Iustitia correctiva refers to the dimension of justice that organises any divergence from the given order in the relationships between citizens. Such divergences can be the result of reciprocal consent, for which buying and selling, or payment for a service rendered, serve as classic examples.

The fact that iustitia correctiva refers to both acceptable and unacceptable divergences from the given order has made the consistent use of the concept difficult. Thomas Aquinas consequently replaced iustitia correctiva with iustitia commutativa as an attempt to address this ambiguity (Huber 1996:153). Iustitia commutativa includes not only the divergences in individual relationships but also those between groups and consequently includes such relationships as those between husbands and wives and between children and parents. Aquinas's more detailed definition did not mean that iustitia correctiva disappeared altogether, but rather led to its retaining its corrective meaning and being moved to the fringes of the different dimensions of justice. Aristotle's two senses of iustitia correctiva consequently developed into civil law and criminal law. Justice in its narrow sense therefore developed three dimensions: iustitia distributiva, iustitia commutativa and iustitia correctiva (Huber 1996:153).

According to Huber, the flows of power in democracies have changed to such an extent that iustitia commutativa is becoming the dominant form of justice. This is very clear in the external changes South Africa is confronted with, as was outlined in the paragraphs above. The ability of the state to guarantee and enact justice - especially in the sense of iustitia commutativa and iustitia correctiva - is clearly diminishing. Huber interprets this dominance of iustitia commutativa as meaning that justice is realised primarily in the relationships between members of society at the marketplace (e.g. Huber 1996:151ff.). The autonomous self-control of the market is understood to be the most trustworthy protector of justice. According to this notion, the state should respect the autonomy of the market by interfering as little as possible. The state is in the first instance responsible for creating a fruitful institutional environment by ensuring stability of the law. 
This is, of course, a significant social ethical challenge and is being enacted in South Africa in a way that clearly does not distribute resources and opportunities in a just manner. This challenge is exacerbated when one views a further external process that influences South African institutions and systems, namely regional integration. Regional integration is exerting a significant influence on politics within South Africa as well. In fact, it will in all probability become increasingly difficult to conduct domestic politics without taking wider regional developments into account. Regional integration is a multidimensional process stimulated and facilitated by the Southern African Development Community (SADC) (cf. Saurombe 2012; Cupido, Soko \& Balchin 2010); the African Union (AU) and its New Partnership for Africa's Development (NEPAD) programme (cf. Rukato 2010; Ndayi 2009). It includes matters as diverse as transnational infrastructure (Abuka 2005), regional stock market developments (Piesse \& Hearn 2005), regional customs agreements (Kirk \& Stern 2005), regional security (Hammerstad 2005) and migration (Oucho \& Crush 2001).

A significant internal political process that exerts a direct influence on South African institutions, systems and processes is South Africa's continuing democratic consolidation. The relatively peaceful transition has led to what Beall, Geld and Hassim term a 'fragile stability' (2005:682). They argue that South Africa can be termed (relatively) stable, because it has transitioned to a non-racial democratic regime; the state is accepted as the legitimate political authority within the country's borders; the state machinery of the apartheid regime has been 'substantially reformed'; and policies have been formulated and institutions established aimed at economic and political stability (Beall, Geld \& Hassim 2005:682). These internal political characteristics, more importantly, have been able to contribute to the persistence, durability and resilience of the South African democratic system - the defining characteristics of democratic consolidation (Burnell \& Calvert 1999:3-4).

Despite the positive signs, however, the South African process of democratic consolidation is at best fragile. Beall, Geld and Hassim (2005:682) ascribe this fragility to 'poverty and inequality, unemployment, HIV/AIDS and personal and property insecurity'; the maintenance of 'existing social fractures - faultlines' and the emergence of 'new fractures created' (2005:683); and the fact that 'ties and linkages between state and society remain uneven in breadth and depth, and there remains considerable potential for stability to break down or evolve into stasis' (2005:683). Despite the usefulness of these signs for sketching a broader picture of the fragility of the South African political system, one should attempt to place these - and other - South African realities within the context of the established discourse on democratic consolidation. In this respect the overview provided by Burnell and Calvert (1999) proves helpful.

Possibly one of the best known attempts - and its succinct nature plays a major role in why it is so well known - is
Huntington's double-turnover test (Burnell \& Calvert 1999:18). According to this definition, a country is democratic if a ruling party can relinquish power peacefully after an electoral defeat. But this definition has yet to be tested in South Africa, making it less relevant for our argument. Linz and Stepan provide a more complex definition, in which they connect the 'behavioural, attitudinal and constitutional dimensions' of democracy with reference to 'a lively civil society, a relatively autonomous political society, the rule of law, a useable state bureaucracy and an economic society' (Burnell \& Calvert 1999:18). The resulting definition of democratic consolidation is 'a political regime in which democracy as a complex system of institutions, rules, and patterned incentives and disincentives has become, in a phrase, 'the only game in town' (Burnell \& Calvert 1999:19). Coupled with the requirement that democracy also needs to be viewed as legitimate (Merkel in Burnell \& Calvert 1999:19) in order to withstand both internal crises and external shocks (Schedlert in Burnell \& Calvert 1999:18), it is clear that South Africa's democracy is indeed relatively stable but fragile, as the factors highlighted by Beall, Geld and Hassim (2005) not only point to potential challenges in remaining legitimate, but can also be viewed as representing the continuing internal crisis.

It is clearly imperative for the practitioners of Christian ethics to develop and apply responses that consciously reflect on the norms of institutions, systems and processes, particularly in South Africa. A key question is how social ethicists can go about interpreting and responding to the changes outlined above. With reference to the fourth principle of contemporary social ethics elucidated by Bedford-Strohm et al. (2007) above, work done on justice by the German social ethicist is illustrative of a social ethical interpretation of the major external and internal developments experienced in South Africa.

\section{On social ethics in South Africa}

The previous section showed that the extent of (political) developments experienced in South Africa would seem to indicate the utility of social ethical reflection. In this section the results of an investigation into the status of recent social ethical reflection in South Africa are systematised.

\section{Methodological considerations}

The investigation was conducted by collecting and analysing peer-reviewed articles written from or with an explicit ethical perspective and published in South African theological journals that either focus on or include systematic theological research. The discussion in the previous section was used as the basis for operationalising the definition of social ethics as a form of Christian ethics concerned with the norms of institutions, systems and processes. The search was limited to the last decade as the investigation focused on recent ethical reflection. The articles were analysed to identify the presence of explicit reflection from a social ethical perspective and/or the presence of social ethical themes. 
The operationalised research question has a number of features that require further clarification:

- 'peer-reviewed articles': the review is aimed at systematising existing work and mapping the field of academic reflection

- 'ethical perspective': articles need to provide evidence of reflection on the concept of ethics. Only articles in which the word 'ethics' is included in keywords are included in the investigation

- 'South African theological journals that either focus on or include systematic theological research': articles from journals based in South Africa were collected, namely Acta Theologica, Scriptura, Journal of Theology for Southern Africa, Verbum et Ecclesia, HTS Teologiese Studies/Theological Studies, Nederduitse Gereformeerde Teologiese Tydskrif

- 'the presence of explicit reflection from a social ethical perspective and/or the presence of social ethical themes': a 'social ethical perspective' would require reference to the academic field of social ethics, whereas 'social ethical themes' refers to themes that satisfy the definition of social ethics provided in the previous section.

The operationalised research question forms the basis for a review with particular characteristics, namely that it is qualitative and to a certain extent multidisciplinary.

As is the case with any study of this nature, this investigation also has very specific limitations:

- Possibly the most significant limitation is that the study will necessarily focus only on English and Afrikaans articles.

- Only digitised peer-reviewed articles are investigated, which implies that substantive reflection on the topic in books, outside academia and in peer-reviewed articles that have not yet been digitised are excluded, whilst systematic theological or ethical reflection in journals devoted to other disciplines is excluded from the study. For practical considerations they are simply not included in the present study.

- Lastly, keywords assigned to the articles for identification of the content of the article, may present a further limitation. It could be the case that articles with a significant amount of ethical reflection may not include the word 'ethics'.

Practically this means that the investigation made use of the respective journals' websites and searched for articles of the past 10 years that were published with the word 'ethics' included in any of their keywords or titles. These articles were analysed qualitatively and systematised for key social ethical themes and social ethical reflection as such. The following section discusses the results of this analysis.

\section{Results}

In systematising my analysis of the results, I made a distinction between articles expressly written from a social ethical perspective and articles that covered social ethical themes.
Articles that covered social ethical themes without reference to social ethics as a field, vastly outnumbered articles that made use of an expressly social ethical perspective. In fact, only two articles were found that fit the latter category. In his article 'The vocation of the Reformed ethicist in the present South African society' De Villiers argues for the development of 'an adequate, contemporary Christian social ethics' (De Villiers 2005:526) as an ethics of responsibility (2005:527). According to De Villiers, social ethics as an ethics of responsibility will do justice 'to both the Christian moral tradition and the achievements of modernisation, including the development of modern societies into relatively independent social systems' and make it possible to 'take adequate account in Christian social ethics of the different cultures of the peoples of South Africa' (De Villiers 2005:527). Freudenberg (2009), in his article 'Economic and social ethics in the work of John Calvin', traces the development of economic and social ethics after the Reformation, and emphasises elements in Calvin's work on the topic. He concludes by synthesising these elements from Calvin's work into three 'markers' of contemporary Christian (social) ethics. These markers are the 'gift of liberty', the 'gift of righteousness' and the 'gift of koinonia' (Freudenberg 2009:639-640).

Articles that cover social ethical themes can be grouped together in four categories, namely articles on human dignity, the ethics of responsibility, ecology and public theology. The majority of the articles on human dignity and responsibility can be connected to a single initiative or theorist, and one finds a close connection between articles on economic ethics and public theology. Each of these theme complexes will be discussed further below with reference to some of the significant contributions within the respective theme complexes. All the articles included in this investigation are listed in the extensive bibliography.

Human dignity is consistently expounded as a concept that has institutional and systemic implications. Koopman's (2010) article 'Human dignity in Africa: A Christological approach' is a case in point. He identifies the causes of the violation of human dignity in (South) Africa as inequality and poverty (2010:214-242), its disease burden (2010:243), racism and sexism (2010:243), crime and corruption (2010:244), ecological challenges (2010:244) and abusive cultural practices (2010:245). These institutional and systemic causes of the violation of human dignity then, as implied by Koopman's argument, require a Christological response. In their contributions De Villiers (2010) and Vorster (2011) expand the conceptualisation of human dignity - and in fact deepen its social ethical reach - by inquiring about the limits of human dignity and the relationship between human dignity and the dignity of non-human inhabitants of the planet.

On a meta-ethical level both Vorster (2008) and De Villiers (2010) initiate a discussion between so-called 'humanist' (Vorster 2008:196) conceptions of human dignity and Christian ethical conceptions. De Villiers (2010:266) cautions against 
definitions of human dignity that make uncritical use of the notion of 'autonomy' and that do not include responsibility in their conceptualisations of human dignity (De Villiers 2010:267). He then proceeds by critically identifying various dimensions such as the ontological ('all human beings have human dignity, because it is bestowed on them as a gift in the act of God's creation and the justification of human beings'), the experiential - '[human dignity] becomes an experienced reality for an individual when it is internalised in a positive attitude' - and the normative:

human dignity entails that the carrier has the responsibility to act in a dignified way of self-respect ... Other human beings, but also institutions such as the state, in turn have the responsibility to respect the human dignity of the carrier. (De Villiers 2010:268)

This leads him to the conclusion that human dignity 'entails that the reality of human dignity bestowed on human beings by God has to be actualised in self-respect, responsible moral behaviour and respectful treatment by others' (De Villiers 2010:268).

A number of articles on human dignity were also the result of a coordinated effort within Old Testament studies aimed at connecting the Decalogue to the topic. Contributions by Bosman (2011), Claasens (2011), Holter (2011), Van Zyl (2011) and to a limited extent Lawrie (2011) can be mentioned in this regard. This rather novel initiative seems to have laid the foundation for innovative and in a sense unconventional results. Claasens, for example, argues that reading the commandment to keep the Sabbath holy in the framework of human dignity leads to (re)considering the nature of work in society, and also interrogates 'the quality and the degree to which this work contributes to a sense of well-being and gratification' (Claasens 2011:75) - a characteristic social ethical theme. Van Zyl, writing about the commandment that prohibits adultery, comes to the provocative conclusion that the legalistic implementation of the commandment will not address sexual abuse and misuse of women. He argues that the commandment will only be understood and applied adequately if it is treated within its 'social relationship function' (Van Zyl 2011:125). According to him, the ' original social function' of the prohibition against adultery was the 'stabilizing of social relations in the community', and that its transformation from community wisdom to legal injunction and its incorporation into cultic laws severely compromised its social function (Van Zyl 2011:123-124).

A second theme incorporates articles that reflect on or develop an ethics of responsibility further. Here the role of the ethicist Etienne de Villiers is significant: virtually without exception, the articles are either written by him or reflect on his ethics of responsibility. One interesting exception is an article by De Gruchy (2009), provocatively entitled 'Dealing with our own sewage: Spirituality and ethics in the sustainability agenda'. In this article he connects ethical responsibility to a further complex of themes (to which we return below), namely articles on ecological issues. De Gruchy develops an ethics of 'the Jordan River', which basically contextualises and focuses on ethics of responsibility on current ecological challenges (De Gruchy 2009:61). He connects the 'freedom from' of liberation struggles - reminding the reader that 'there remain things that we need to be set free "from", from hunger, racism, HIV and AIDS, and gender-based violence' (De Gruchy 2009:62) - to 'freedom for', namely the Promised Land as 'the place where we need to be free "to" live in a way that respects the constraints and limitations that the earth provides' (De Gruchy 2009:62).

The rest of the articles on the theme can be connected directly to the person of Etienne de Villiers. He develops ethics of responsibility in a way that satisfies the criteria set out to define social ethics particularly in his contributions 'Prospects of a Christian ethics of responsibility (part 1): An assessment of an American version' (De Villiers 2006b) and 'Prospects of a Christian ethics of responsibility (part 2): An assessment of three German versions' (2007). Even though these articles have a strong meta-ethical thrust, bringing five versions of an ethics of responsibility into dialogue with one another, the starting point is clearly the ambit of social ethics. On the one hand, De Villiers criticises Hans Jonas's influential exposition of an ethics of responsibility as too prospective in character to the extent that it neglects the retrospective elements of responsibility (cf. De Villiers 2007:89); he rejects the elevation of responsibility as 'substantive moral principle' by both Schweiker and Jonas (De Villiers 2006b:484), and refutes the contention that a 'universal, realistic foundation' is needed for an ethics of responsibility (De Villiers 2006b:470). He nonetheless does this within the framework of his broad agreement with the systemic or societal challenges to which an ethics of responsibility should react. Huber's identification, for example, of 'collective crimes of obedience', 'the globalisation of modern technology', 'the ambivalence of the project of modernity' (De Villiers 2007:91) and 'the increasing moral plurality' and 'the increasing autonomy of partial systems of society' (De Villiers 2007:104) seem to be endorsed by De Villiers. This is - at least partly - reflected in his identification of responsibility as a qualification of Christian ethics, requiring that consequences of actions should be taken into account, including the consequences such actions would have for the preservation of the environment and for the survival and quality of life of future generations' (De Villiers 2007:107).

An application of De Villiers's approach can be found in the (earlier) article on an ethics of responsibility and issues of public morality (De Villiers 2003). In this article De Villiers concludes that an ethics of responsibility can aid attempts at improving public morality, namely by enabling persons to take 'own responsibility' for their actions (De Villiers 2003:33$34)$, to take 'the concrete situation seriously' (2003:34-35), to take 'role responsibilities seriously' (2003:35-36) and to take 'consequences of decisions and actions into account' (De Villiers 2003:36).

A third theme, closely connected to the discussion above, is ecology. As was mentioned above, the article by De Gruchy is illustrative of this connection. Pillay's (2011) article 'The church and the environment: On being down to earth in a consumerist era' can also be mentioned in this regard. With reference to work done by Conradie and from an eco- 
feminist perspective, Pillay uses fundamental critiques of both anthropocentrism and patriarchy as point of departure (2011:185) to argue that the church 'needs to release "holiness" from the shackles of the power of hierarchy if it wants to shape a (uniquely) Christian response to the (already manifested and continuously emerging) ecological crises' (Pillay 2011:192). This leads us to the article by Conradie (2011) included in the survey. Some might be surprised that only one article from his expansive oeuvre on the topic satisfied the operationalised research question set out above. This can be explained with reference to one of the identified weaknesses of the investigation itself, namely including only articles with 'ethics' as a keyword. However, it might be argued, conversely, that an even more qualitative approach could possibly have led to even more methodological limitations. That being said, ecology has clearly emerged as a significant theme, and hence Conradie's contribution - possibly the most important South African theologian working on this theme - has been included. Conradie presents an interesting argument, which he structures in terms of seven 'spiritual "stations" towards the sanctification of the whole earth' (Conradie 2011:156).

A last complex of themes can be found in articles on or from the perspective of public theology. Again it is certainly the case that this investigation did not include all the articles published on public theology in South African journals, principally because this would have gone beyond the aim of this article and the investigation itself. The presence of articles on public theology is an important impulse for considering the relation between classical social ethics and this emerging field. A key challenge is - as with most emerging phenomena - the definition of the field. BedfordStrohm (2010b:19) contrasts public theology - or 'a public theological model' - with a utopian model. Whereas the latter is inspirational, it might lack reflection 'upon the concrete effects of certain possible mechanisms, including possible unintended counterproductive effects of mechanisms which at first sight seem especially ethically valuable' (BedfordStrohm 2010b:19). A public theological model also has a 'natural closeness' to an ethics of responsibility as it 'sees the reflection on the consequences of its considered alternatives for action as an integral part of its ethical argument' (Bedford-Strohm 2010b:19). He then proceeds to illustrate the meaning of a public theological approach with reference to the economy. It is interesting to note that the contributions on public theology (or the contributions in which a connection is made between public theology and ethics) are all written by authors residing outside South Africa. This goes for the important contributions of Bedford-Strohm and a further contribution on public theology and Christian sexual ethics in South Africa (see Bedford-Strohm 2010a, 2010b, 2012; Haspel 2004).

\section{Concluding remarks}

When taken together, three concluding features related to the status of, and need for social ethical reflection in South Africa, can be identified.
Firstly, with regard to the need for social ethics in South Africa, it can be noted that significant institutional and systemic changes continue to take place, and that reflection on their norms are imperative for contributing to a truly humane society. There is a clear need for social ethical reflection in South Africa.

Secondly, with regard to the status of social ethics in South Africa, it was shown that social ethical reflection is clearly hugely unbalanced. A great number of articles are written on social ethical themes, but very few are written from an explicitly social ethical perspective. This might have significant implications for the rigour, depth and breadth of social ethical reflection in South Africa. The field of social ethics provides the tried and tested resources that can and should be applied to the norms of institutions, systems and processes. Neglecting or not taking cognisance of these resources will surely impact on the eventual treatment of social ethical themes.

It should be noted, thirdly, that few of the social ethical themes covered in the past decade seem to connect explicitly to the major economic and political changes experienced in South Africa. This can be ascribed to a number of factors, including the limited number of theologians in the field, the perception within and outside theology that theology does not have the legitimacy to play a role outside the church and - as was argued above - the fact that the disjunction between thematic social ethical reflection and reflection from within the field - or taking cognisance of the field - is bound to lead to a rather haphazard collection of themes.

On the basis of the argument presented above, the following conclusion seems appropriate: social ethics as a field clearly has an important role to play in South Africa as the country is experiencing significant processes of institutional and systemic changes. However, the disciplinary resources accumulated in the field need to be re-appropriated, contextualised and developed further in order to address these realities in a relevant, reflective and grounded manner, in order to eventually maximise the potential impact of contributions to this field of study.

\section{Acknowledgements Competing interests}

The author declares that he has no financial or personal relationship(s) which may have inappropriately influenced him in writing this article.

\section{References}

Abuka, C., 2005, 'Infrastructure, regional integration and growth' in J.J. Teunissen \& A. Akkerman (eds.), Africa in the world economy: The national, regional and international challenges, pp. 122-128, Fondad, The Hague.

Adu-Gyamfi, Y., 2011, 'Indigenous beliefs and practices in ecosystem conservation Response of the Church', Scriptura 107, 145-155.

Baker, D. \& More, J., 2003, 'Taking the quandary out of Christian ethics', Journal of Theology for Southern Africa 115(March), 5-17.

Baumann, G., 2009, 'Wisdom and ethics - The contribution of sapiential ethics for Old Testament Ethics', Verbum et Ecclesia 30(1), 15-24. http://dx.doi.org/10.4102/ ve.v30i1.61 
Beall, J., Gelb, S. \& Hassim, S., 2005, 'Fragile stability: State and society in democratic South Africa', Journal of Southern African Studies 31(4), 681-700.

Bedford-Strohm, H., Reihs, S., Wegner, G., Jähnichen, T. \& Reuter, H-R., 2007, Kontinuität und Umbruch im deutschen Wirtschafts- und Sozialmodell, Gütersloher Verlagshaus, Gütersloh. (Jahrbuch Sozialer Protestantismus, I).

Bedford-Strohm, H., 2010a, 'Human dignity: A global ethical perspective', Scriptura $104,211-220$

Bedford-Strohm, H., 2010b, 'Public theology and the economy in a globalizing world', Nederduitse Gereformeerde Teologiese Tydskrif 51(1/2), 15-23.

Bedford-Strohm, H., 2012, 'Food justice and Christian ethics', Verbum et Ecclesia 33(2), Art. \#768, 6 pages. http://dx.doi.org/10.4102/ve.v33i2.768

Bosman, H. 2011, 'Bookends of Old Testament ethics: The first and tenth commandments and human dignity', Scriptura 106, 93-100.

Bredenkamp, D.S.M., 2002, 'Paulus oor seksuele selfbeheersing - enkrateuomai en akrasia in 1 Korintiërs 7', Nederduitse Gereformeerde Teologiese Tydskrif 43(3/4) 342-353.

Burnell, P. \& Calvert, P., 1999, 'The resilience of democracy: An introduction', Democratization 6(1), 1-32. http://dx.doi.org/10.1080/13510349908403594

Castells, M., 2010, The power of identity, 2nd edn., Wiley Blackwell, Malden, MA

Claassens, L.J.M., 2011, 'Sabbath reconsidered: Human dignity and the fourth Commandment', Scriptura 106, 71-80.

Conradie, E.M., 2011, 'The Church and the environment: Seven stations towards the sanctification of the whole Earth', Scriptura 107, 156-170.

Crane, A., Matten, D. \& Spence, L., 2008a, 'Globalization and CSR', in A. Crane, D. Matten \& L. Spence (eds.), Corporate social responsibility: Readings and cases in a global context, pp. 456-460, Routledge/London/New York.

Crane, A., Matten, D. \& Spence, L., 2008b, 'The case for and against CSR', in A. Crane, D. Matten \& L. Spence (eds.), Corporate social responsibility: Readings and cases in a global context, pp. 21-25, Routledge, London/New York. PMCid:2881303

Cupido, M., Soko, M. \& Balchin, N., 2010, 'SADC and the global economic crisis: Origins, impacts and state policy responses', Africa Insight 40(3), 168-182.

De Gruchy, S., 2009, 'Dealing with our own sewage: Spirituality and ethics in the sustainability agenda", Journal of Theology for Southern Africa 134, 53-65.

De Lange, M.C., 2012, 'Dealing with bioethical dilemmas: A survey and analysis of responses from ministers in the Reformed Churches in South Africa', HTS Teologiese Studies/Theological Studies 68(1), Art. \#882, 10 pages. http://dx.doi. org/10.4102/hts. v68i1.882

De Villiers, D.E., 2002, 'Euthanasia and assisted suicide: A Christian ethical perspective', Acta Theologica Supplementum 3, 35-47.

De Villiers, E., 2003,' A Christian ethics of responsibility: Does it provide an adequate theoretical framework for dealing with issues of public morality?', Scriptura 82 23-38.

De Villiers, D.E., 2005, 'The vocation of Reformed ethicist in the present South African society', Scriptura 89, 521-535.

De Villiers, D.E., 2006a, 'Gee die Bybel nog vandag aan ons morele oriëntering oor kwessies soos homoseksualiteit?', Acta Theologica 26(1), 54-78.

De Villiers, D.E., 2006b, 'Prospects of a Christian ethics of responsibility (part 1): An assessment of an American version', Verbum et Ecclesia 27(2), 468-487 http:// dx.doi.org/10.4102/ve.v27i2.159

De Villiers, D.E., 2007, 'Prospects of a Christian ethics of responsibility (part 2): An assessment of three German versions', Verbum et Ecclesia 28(1), 88-109 http:// dx.doi.org/10.4102/ve.v28i1.99

De Villiers, D.E., 2012, 'The distinctiveness of Christian morality - Reflections after 30 years', Verbum et Ecclesia 33(2), Art. \#758, 7 pages. http://dx.doi.org/10.4102/ ve.v33i 2.758

De Villiers, D.E., 2010, 'The recognition of human dignity in Africa: A Christian ethics of responsibility perspective', Scriptura 104, 263-278.

Draper, J.A., 2009, 'Imitating Jesus, yes - but which Jesus? A critical engagement with the ethics of Richard Burridge in Imitating Jesus: An inclusive approach to New Testament ethics', HTS TeologieseStudies/Theological Studies 65(1), Art. \#164, 5 pages. http://dx.doi.org/10.4102/hts.v65i1.164

Du Toit, A., 2006, 'Christenidentiteit en etiek in Romeine', Nederduitse Gereformeerde Teologiese Tydskrif 47(3/4), pp. 429-442.

Du Toit, C., 2005, 'Etsi Deus non daretur? Meta-Christian values in a post-democratic world', Journal of Theology for Southern Africa 123, 61-73.

Efthimiades-Keith, H., 2010, 'Judith, feminist ethics and feminist biblical/Old Testament interpretation' Journal of Theology for Southern Africa 138, 91-111.

Evangelische Kirche in Deutschland (EKD), 2006, Gerechte Teilhabe. Befähigung zu Eigenverantwortung und Solidarität. Eine Denkschrift des Rates der EKD zur Armut in Deutschland, Gütersloher Verlagshaus, Gütersloh.

Franken, C., 2012, 'Paulus se hantering van eksterne stressors, en die verhouding tussen identiteit, etiek en etos in Filippense', HTS Teologiese Studies/Theological Studies 68(1), Art. \#1148, 11 pages. http://dx.doi.org/10.4102/hts. v68i1.1148

Freudenberg, M., 2009, 'Economic and social ethics in the work of John Calvin', HTS Teologiese Studies/Theological Studies 65(1), Art. \#286, 7 pages. http://dx.doi. org/10.4102/hts.v65i1.286

Garriga, E. \& Melé, D., 2008, 'Corporate social responsibility theories: Mapping the territory', in A. Crane, D. Matten \& L. Spence (eds.), Corporate social responsibility: Readings and cases in a global context, pp. 76-106, Routledge, London/New York.
Gouws, A., 2009, 'A gender perspective on social welfare and religion in Paarl through the lens of a feminist ethics of care', Journal of Theology for Southern Africa 133, the-73.

Groenewald, A., 2011, 'Isaiah 1:2-3, ethics and wisdom. Isaiah 1:2-3 and the Song of Moses (Dt 32): Is Isaiah a prophet like Moses?', HTS Teologiese Studies/Theological Studies 67(1), Art. \#954, http://dx.doi.org/10.4102/hts.67i1.954

Hale, F., 2005, 'Baptist ethics of conscientious objection to military service in South Africa: The watershed case of Richard Steele', Acta Theologica 25(2), 18-44.

Hammerstad, A., 2005, 'Domestic threats, regional wolutions? The challenge of security integration in Southern Africa', Review of International Studies 31, 69-87. http://dx.doi.org/10.1017/S0260210505006303

Harris, J.I., 2002, 'The king as public servant: towards an ethic of public leadership based on virtues suggested in the wisdom literature of the Older Testament', Journal of Theology for Southern Africa 113, 61-73.

Haspel, M., 2004, 'Christian sexual ethics in a time of HIV/AIDS - A challenge for public theology' Verbum et Ecclesia 25(2), 480-501. http://dx.doi.org/10.4102/ ve.v25i2.282

Hays, C.M., 2012, 'Provision for the poor and the mission of the church: Ancient appeals and contemporary viability', HTS Teologiese Studies/Theological Studies 68(1), Art. \#1218, 7 pages. http://dx.doi.org/10.4102/hts.v68i1.1218

Hoffman, S. \& Buitendag, J., 2010, "n Ekoteologiese besinning oor die Christelik-etiese implikasies van stamselnavorsing en -terapie', HTS Teologiese Studies/Theological Studies 66(1), Art. \#333, 10 pages. http://dx.doi.org/10.4102/hts.v66i1.333

Holter, K., 2011, 'The second commandment and the question of human dignity in Africa: A creation-theological perspective', Scriptura 106, 51-60.

Honecker, M., 1995, Grundriß der Sozialethik, Walter de Gruyter, Berlin/New York.

Höver, H., 2005, 'Corporate governance? Ethical evaluation of the Second King Report in the light of Peter Ulrich's integrative economic ethics', Nederduitse Gereformeerde Teologiese Tydskrif 46(1/2), 114-128.

Huber, W., 1996, Gerechtigkeit und Recht. Grundlinien christlicher Rechtsethik, Gütersloher Verlagshaus, Gütersloh.

Huber, W., 2004, 'Unsterblichkeit und Würde. Kant zu Ehren', in Evangelische Kirche in Deutschland, viewed 20 May 2013, from http://www.ekd.de/vortraege/ huber/030216_huber_kant.html

Huber, W., 2012, 'After Fukushima: The precautionary principle revisited', Verbum et Ecclesia 33(2), Art. \#736, 6 pages. http://dx.doi.org/10.4102/ve.v33i2.736

Kirk, R. \& Stern, M., 2005, 'The new southern African Customs Union Agreement', The World Economy 28(2), 169-190. http://dx.doi.org/10.1111/j.1467-9701. 2005.00619.x

Kirn, H., 2011, 'Human dignity and ethical treatment: Remarks on family concepts and family life in the era of the Reformation', Nederduitse Gereformeerde Teologiese Tydskrif 52(1), 57-60.

Kok, J., 2011, 'Mission and ethics in Galatians', HTS Teologiese Studies/Theological Studies 67(1), Art. \#896, 10 pages. http://dx.doi.org/10.4102/hts.v67i1.896

Kok, J., 2012, 'Mission and Ethics in 1 Corinthians: Reconciliation, corporate solidarity and other-regard as missionary strategy in Paul', HTS Teologiese Studies/ Theological Studies 68(1), Art. \#1222, 11 pages. http://dx.doi.org/10.4102/hts. v68i1.122

Koopman, N., 2002, 'Christian ethics in post-apartheid South Africa - a Reformed perspective', Nederduitse Gereformeerde Teologiese Tydskrif 43(3/4), 443-454.

Koopman, N., 2003, 'The dis-(otherly)abled and public morality', Scriptura 82, 72-81.

Koopman, N., 2007a, 'Doing ethics in communion: Some lessons from the theology of Dirkie Smit', Nederduitse Gereformeerde Teologiese Tydskrif 48(1/2), 366-375.

Koopman, N., 2007b, 'Towards a human rights culture in South Africa: The role of moral formation', Nederduitse Gereformeerde Teologiese Tydskrif 48(1/2), 107118.

Koopman, N., 2010, 'Human dignity in Africa: A Christological approach', Scriptura 204, 240-249.

Körtner, U.H.J., 1999, Evangelische Sozialethik: Grundlagen und Themenfelder, Vandenhoeck \& Ruprecht, Göttingen.

Kretzschmar, L., 2007, 'The formation of moral leaders in South Africa: A Christianethical analysis of some essential elements', Journal of Theology for Southern Africa $128,18-36$

Kretzschmar, L., 2011, 'Can morality be taught? A reflection on teaching theological ethics at a tertiary level in the Unisa Open and Distance Learning Model', Journal of Theology for Southern Africa 141, 61-80.

Lategan, L.O.K., 2002a, "n Kritiese evaluering van die kompromie as etiese figuur in die teologiese etiek van J. Douma, J.A. Heyns, S.J. Ridderbos en W.H. Velema', Acta Theologica 22(1), 57-76.

Lategan, L.O.K., 2002b, 'Die kompromie in die etiek: Méér as net'n besluitnemingsfiguu in die etiek', Nederduitse Gereformeerde Teologiese Tydskrif 43(3/4), 478-486.

Lategan, L.O.K., 2008, 'Employing theological ethics to draft a professional ethic in research', Nederduitse Gereformeerde Teologiese Tydskrif 49(3/4), 177-192.

Lawrie, D., 2011, 'Of human indignity and the limits of ethics', Scriptura 106, 81-92.

Le Bruyns, C., 2007,' Human dignity and moral renewal', Scriptura 95, 202-212.

LenkaBula, P., 2002, 'From the womb into a hostile world: Christian ethics and sexual abuse against children in South Africa', Journal of Theology for Southern Africa $114,55-68$ 
LenkaBula, P., 2005, 'The social and ethical implications of Article 27 of the agreement on trade related aspects of intellectual property rights (TRIPS) on African communities, biodiversity and indigenous knowledge', Journal of Theology for communities, biodiversity and

Loader, J.A., 1971, 'Israel - land, volk en staat: 'n Bespreking van die besinning van die Nederlandse Hervormde Kerk', HTS Teologiese Studies/Theological Studies 28 104-106.

Loader, J.A., 1975, 'Aspekte van menslike mag in die Ou Testament', dissertation, Department Old Testament, University of Groningen.

Loader, J.A., 1979, 'An alternative to Johannes Pedersen's power concept', Ou Testamentiese Werkgemeenskap van Suid-Afrika 22/23, 113-129.

Loader, J.A., 1980, 'Ou-Testamentiese perspektiewe oor politieke en sosio-ekonomiese mag', HTS Teologiese Studies/Theological Studies 36, 50-57.

Loader, J.A., 1982, 'Politiek, ekonomie en kultuur in die tyd van Salomo', in F.E. Deist (red.), Die Bybel leef, bl. 88-96, JL van Schaik, Pretoria.

Loader, J.A., 1984, 'Die etiese Ou-Testamentici in Nederland tussen 1870 en 1914', DTh- proefskrif, Departement Kerkgeskiedenis, Universiteit van Suid-Afrika.

Loader, J.A., 1987, 'Image and order: Old Testament perspectives on the ecological crisis', in W.S. Vorster (ed.), Are we killing God's earth?, pp. 24-31, Unisa, Pretoria.

Loader, J.A., 1991a, 'Life, wonder and responsibility: Some thoughts on ecology and Christian mission', Missionalia 19, 44-56.

Loader, J.A., 1991b, 'Omgewing, lewe en belewing: Oor homo religiosus, die kunste en die omgewing', De Arte 43, 35-39.

Loader, J.A., 1992, 'Seeing God with natural eyes: On Job and nature', Old Testament Essays 5, 346-360.

Loader, J.A., 1998, 'Johannes Brahms, agnosticism and some other wisdom', Skrif en Kerk 19(3), 616-627.

Loader, J.A., 2002, 'Alttestamentliche Notizen zum Thema "Evangelische Kirchen und Demokratie"', Amt und Gemeinde 53, 150-169.

Loader, J.A., 2004a, 'Begegnung mit Gott als Zentralbegriff der Niederländischen "Ethischen Theologie"', in M. Witte (ed.), Gott und Mensch im Dialog: Festschrift für Otto Kaiser zum 80. Geburtstag, pp. xx-yy, De Gruyter, Berlin.

Loader, J.A., 2004b, 'Virtue between command and advice', Old Testament Essays 17, 416-434

Loader J.A., 2012, 'The problem of money in the hand of a fool', HTS Teologiese Studies/Theological Studies 68(1), Art. \#1266, 9 pages. http://dx.doi.org/10.4102/ hts.v68i1.1266

Lietaert Peerbolte, B.J., 2012, 'Morality and boundaries in Paul', HTS Teologiese Studies/Theological Studies 68(1), Art. \#1240, 7 pages. http://dx.doi.org/10.4102/ hts. v68i1.1240

Malherbe, A.J., 2012, 'Ethics in context: The Thessalonians and their neighbours', HTS Teologiese Studies/Theological Studies 68(1), Art. \#1214, 10 pages. http://dx.doi. org/10.4102/hts.v68i1.1214

Müller, B.A., 2006, 'The role of worship and ethics on the road towards reconciliation' Verbum et Ecclesia 27(2), 641-663.

Müller, R., 2011, 'Christianity and globalisation: An alternative ethical response', HTS Teologiese Studies/ Theological Studies 67(3), Art. \#963, 7 pages. http://dx.doi. org/10.4102/hts.v67i3.963

Myburgh, S.J., 2010, 'Prejudice as moral action in Christian ethical decision-making', Verbum et Ecclesia 31(1), Art. \#89, 6 pages. http://dx.doi.org/10.4102/ve.v31i1.89

Naudé, P.J., 2003,' 'We cannot just continue as if nothing has happened between us Sola Gratia and restorative justice', Scriptura 84, 402-409.

Naudé, P.J., 2008, 'What has Accra to do with New York? An analysis of moral discourse in the Accra Confession', Nederduitse Gereformeerde Teologiese Tydskrif 49(3/4), 206-216.

Ndayi, Z., 2009, 'Contextualising NEPAD: Regionalism, plurilateralism and multilateralism', South African Journal of International Affairs 16(3), 371-387. http://dx.doi.org/10.1080/10220460903495132

Nel, P.J., 2008, 'Morality and religion in African thought', Acta Theologica 28(2), 33-47.

Novakovic, L., 2009, "'Yet even the dogs eat the crumbs that fall from their masters' table": Matthew's Gospel and economic globalisation', HTS Teologiese Studies/ Theological Studies 65(1), Art. \#321, 7 pages. http://dx.doi.org/10.4102/hts. v65i1.321

Oucho, J. O. \& Crush J., 2001, 'Contra free movement: South Africa and the SADC migration protocols', Africa Today 48(3), 139-159. http://dx.doi.org/10.1353/ migration proto

Piesse, J. \& Hearn, B., 2005, 'Regional integration of equity markets in subSaharan Africa', South African Journal of Economics 73(1), 36-52. http://dx.doi. org/10.1111/j.1813-6982.2005.00003.x

Pillay, M.N., 2011, 'The Church and the environment: On being down to Earth in a Consumerist era', Scriptura 107, 184-198.

Punt, J., 2011, 'The decalogue in the New Testament: Tradition, ethos, and identity', Scriptura 106, 101-114.

Raath, A., 2008, 'Conjugal union and moral dignity - the Early Reformers on the mora context of marriage and the minimum standards for sustaining moral integrity in society', Nederduitse Gereformeerde Teologiese Tydskrif 49(3/4), 217-239.

Rauhaus, A., 2009, 'Is an ethical status confessionis possible?', HTS Teologiese/ Theological Studies 65(1), Art. \#285, 6 pages. http://dx.doi.org/10.4102/hts. v65i1.285

Reihs, S., Wegner, G., Bedford-Strohm, H., Jähnichen, T., \& Reuter, H., 2007, Kontinuität und Umbruch im deutschen Wirtschafts- und Sozialmodell, Güterslohe Verlagshaus, Gütersloh. (Jahrbuch Sozialer Protestantismus, I).
Roth, D.T., 2012, 'Missionary ethics in Q 10:2-12', HTS Teologiese Studies/Theological Studies 68(1), Art. \#1215, 7 pages. http://dx.doi.org/10.4102/hts. v68i1.1215

Rukato, H., 2010, Future Africa: Prospects for democracy and development under NEPAD, Africa World Press, Asmara.

Saurombe, A., 2012, 'The role of SADC institutions in implementing SADC treaty provisions dealing with regional integration', Potchefstroom Electronic Law Journal 15(2), 453-485. http://dx.doi.org/10.4314/pelj.v15i2.16

Scheffler, E., 2004, 'Jung, the Pentateuch and ethics', Verbum et Ecclesia 25(2), 653675. http://dx.doi.org/10.4102/ve.v25i2.292

Scheffler, E., 2011, 'Luke's view on poverty in its ancient (Roman) economic context: A challenge for today', Scriptura 106, 115-135.

Smit, D.J., 2004, 'Lex orandi, lex credendi, lex (con)vivendi? - Oriënterende inleiding tot liturgie en etiek', Nederduitse Gereformeerde Teologiese Tydskrif 45(3/4) 887-907.

Smit, D.J., 2012, 'Etienne de Villiers as etikus van verantwoordelikheid', Verbum et Ecclesia 33(2), Art. \#735, 6 pages. http://dx.doi.org/10.4102/ve.v33i2.735

Theron, P.M. \& Lotter, G.A., 2012, 'Corruption: How should Christians respond?', Acta Theologica 32(1), 96-117.

Togarasei, L., 'Let everyone be subject to governing authorities: The interpretation of New Testament political ethics towards and after Zimbabwe's 2002 presidential elections', Scriptura 85, 73-80.

Toryough, G.N., 2010, 'The biblical ethics of work: A model for African nations', Verbum et Ecclesia 31(1), Art. \#363, 8 pages. http://dx.doi.org/10.4102/ve.v31i1.363

Van Aarde, A.G., 2012, 'The righteousness of God, begging for the poor and Paul's apostolic mission according to his Letter to the Romans', HTS Teologiese Studies/ Theological Studies 68(1), Art. \#1223, 8 pages. http://dx.doi.org/10.4102/hts. v68i1.1223

Van der Watt, J.G., 2006, 'Familiale beeldgebruik in Johannes 8 en die etiek van die Johannesevangelie', Nederduitse Gereformeerde Teologiese Tydskrif 47(3/4), 737-746.

Van Huyssteen, J.W., 2008, 'Ethics and Christology - Rediscovering Jesus in Evolutionary History', Verbum et Ecclesia 29(2), 492-495. http://dx.doi. org/10.4102/ve.v29i2.45

Van Niekerk, A.C.J., 2012, 'Personal-ethical perspectives in the work of Etienne de Villiers', Verbum et Ecclesia 33(2), Art. \#753, 6 pages. http://dx.doi.org/10.4102/ ve.v33i 2.753

Van Niekerk, A.A., 2011, 'Willie Jonker se Teologiese Etiek', Nederduitse Gereformeerde Teologiese Tydskrif 52(3/4), 585-599.

Van Zyl, D., 2011, 'We have yoked a lion: The 7th commandment and human dignity in Africa', Scriptura 109, 119-132.

Venter, P.M., 2011, 'Congruent ethos in the Second Temple literature of the Old Testament', HTS Teologiese Studies/Theological Studies 67(1), Art. \#965, 13 pages. http://dx.doi.org/10.4102/hts.v67i1.965

Vorster, J.M., 2006,' Die etiek van Regstellende Aksie', Acta Theologica 26(1), 225-248.

Vorster, J.M., 2008, "n Christelike perspektief op menswaardigheid', Nederduitse Gereformeerde Teologiese Tydskrif 49(1/2), 195-205.

Vorster, J.M., 2009, 'An ethics of forgiveness', Verbum et Ecclesia 30(1), 365-383. http://dx.doi.org/10.4102/ve.v30i1.79

Vorster, J.M., 2011, 'An ethics of hope for moral renewal in South Africa', Journal of Theology for Southern Africa 140, 4-19.

Vorster, J.M., 2011, 'A Christian ethical perspective on the moral status of the human embryo', Acta Theologica 31(1), 189-204.

Vorster, J.M., 2012a, 'Christian ethics in the face of secularism', Verbum et Ecclesia 33(2), Art. \#730, 8 pages. http://dx.doi.org/10.4102/ve.v33i2.730

Vorster, J.M., 2012b, 'Managing corruption in South Africa: The ethical responsibility of churches', Scriptura 109, 133-147.

Vorster, N., 2011, 'The relationship between human and non-human dignity', Scriptura 106, 38-47. http://dx.doi.org/10.4314/actat.v31i1.11

Vosloo, R., 2003, 'Public morality and the need for an ethos of hospitality', Scriptura $82,63-71$.

Vosloo, R., 2004a, 'Anderkant etiek? Tradisie, dekonstruksie en verdere weë', Nederduitse Gereformeerde Teologiese Tydskrif 45(3/4), 936-955.

Vosloo, R., 2004b, 'Etiek as optiek? Oor die rol van beelde en verbeelding in die Christelike morele lewe,' Nederduitse Gereformeerde Teologiese Tydskrif 45(1/2), 137-151.

Wendland, H-D., 1971, Einfürung in die Sozialethik, Walter de Gruyter, Berlin/New York.

Williams, D., 2003, 'Spirit of holiness? Moral decline in "Christian" society', Scriptura $82,147-156$

Wolf, E., 1975, Sozialethik: Theologische Grundfragen, Vandenhoeck \& Ruprecht, Göttingen.

Zimmermann, R., 2008, 'The etho-poietic of the parable of the good Samaritan (Lk $10: 25-37)$. The ethics of seeing in a culture of looking the other way', Verbum et Ecclesia 29(1), 269-292 http://dx.doi.org/10.4102/ve.v29i1.16

Zimmermann, R., 2012, 'Mission versus ethics in 1 Corinthians 9? "Implicit ethics" as an aid in analysing New Testament texts', HTS Teologiese Studies/Theological Studies 68(1), Art. \#1216, 8 pages. http://dx.doi.org/10.4102/hts. v68i1.1216 